

\title{
Warburg e Burckhardt
}

\section{Warburg and Burckhardt}

\section{Dr. Cássio da Silva Fernandes ${ }^{*}$}

\begin{abstract}
Resumo
Vários são os sinais emitidos por Aby Warburg, nos escritos da fase final de sua vida, sobre a importância de Jacob Burckhardt como um guia tanto para a compreensão do Renascimento como época histórica autônoma (e, portanto, como campo específico dos estudos históricos), quanto na forma de abordar as relações possíveis entre palavra e imagem nesse período. Há, porém, uma etapa da obra de Warburg em que o historiador suíço se faz presente de modo mais intenso. Trata-se do período dos estudos warburguianos sobre arte e cultura em Florença na segunda metade do século XV, que coincide com a fase final da produção de Burckhardt. Sobre esta problemática coloca-se o presente artigo.
\end{abstract}

\section{Palavras-chave}

Jacob Burckhardt. Aby Warburg. Renascimento. História da Arte. História da Cultura.

\begin{abstract}
There are several signs emitted by Aby Warburg, in the writings of the final period of his life, about the importance of Jacob Burckhardt as a guide for understanding the Renaissance as an autonomous historical epoch (and, therefore, as a specific field of historical studies), and to approach the possible relations between word and image in this epoch. There is, however, a stage in Warburg's work in which the Swiss historian is more present. It is the period of Warburguian studies on art and culture in Florence in the second half of the 15th century, which coincides with the final stage of Burckhardt's production. This article addresses this issue.
\end{abstract}

\section{Keywords}

Jacob Burckhardt. Aby Warburg. Renaissance. Art History. Culture History. 
Vários são os sinais emitidos por Aby Warburg (1866-1929), nos escritos da fase final de sua vida, sobre a importância de Jacob Burckhardt (1818-1897) como um guia tanto para a compreensão do Renascimento como época histórica autônoma (e, portanto, como campo específico dos estudos históricos), quanto na forma de abordar as relações possíveis entre palavra e imagem nesse período. A própria expressão "cultura do Renascimento", presente no título do livro de 1860 , com o qual Burckhardt propôs uma síntese histórica da época, A Cultura do Renascimento na Itália (Burckhardt, 1978), teve um significado central para o desenvolvimento das investigações sobre as quais Warburg se debruçou desde a juventude. É possível dizer que o tema da cultura do Renascimento, sob uma perspectiva de movimento e inter-relações culturais, esteve presente no teor dos estudos de Warburg pelo menos desde seu período na Universidade de Bonn, sendo gestado ali na forma de uma crítica a Johann J. Winckelmann. É o que afirma o próprio Warburg dois anos antes de sua morte, referindo-se ao período de estudos em Bonn:

\begin{abstract}
Se lanço um olhar retrospectivo sobre o significado mais íntimo da minha atividade intelectual, parece-me que já então estava convencido de que era necessário fazer uma correção à tese de Lessing. (...) A correção à doutrina de Lessing, ou mais exatamente à ideia de Winckelmann a respeito da serenidade olímpica da Antiguidade, desenvolveu-se nas décadas sucessivas, baseado num fundamento histórico-cultural, e ainda hoje não posso decerto considerá-la concluída (Warburg, 2018: 39).
\end{abstract}

Trata-se de um trecho da conferência de caráter autobiográfico, ministrada pelo estudioso em 29 de dezembro de 1927, no salão da Kulturwissenschaftiche Bibliothek Warburg [Biblioteca Warburg para a Ciência da Cultura], então sediada em Hamburgo ${ }^{1}$. Embora Burckhardt não seja referido diretamente na conferência, várias são as indicações de sua presença na trajetória do estudioso hamburguês. $\mathrm{Na}$ passagem mencionada acima, o "fundamento histórico-cultural" sobre o qual Warburg afirma assentarse sua crítica à interpretação do Antigo por Winckelmann pode ser interpretado como um desses sinais. Esta hipótese é reforçada pelo fato de que a conferência autobiográfica é coetânea aos cursos ministrados por Warburg, como professor convidado, na Universidade de Hamburgo, sobre a obra de Jacob Burckhardt (Warburg, 2008: 895-901) e sobre "O método da ciência da cultura" (Kunstwissenschaftiche Methode) (Ibidem: 911-920). Com efeito, a conferência de 1927 coincide com a realização desses dois seminários, dos quais sobreviveram anotações em cadernos conservados entre os manuscritos do autor.

Além disso, a referência a Burckhardt na fase final da vida de Warburg pode ser observada no modo como o estudioso de Hamburgo alude ao historiador suíço. Em 1929, na conferência proferida na Biblioteca Hertziana de Roma, "Die römische Antike in der Werkstatt Ghirlandaios" ["O Antigo romano na oficina de Ghirlandaio"], Warburg afirma:

\footnotetext{
Estou convencido de que seja fecundo um estreito contato entre arqueologia, história da arte e uma exata ciência histórica sociológica. Acrescente-se a isso uma nova matéria, que talvez até aqui tenha sido considerada apenas como mera curiosidade. Jacob Burckhardt, que constitui para mim sempre um guia, indicou com clareza este campo. "As festividades italianas, em sua forma mais elevada, exibem uma verdadeira transição da vida para a arte"2 (Warburg, 2018: 198, grifo nosso).
}

Antes disso, em 1925, por ocasião da homenagem a Franz Boll, que teve lugar na Kulturwissenschaftliche Bibliothek Warburg de Hamburgo, na palestra de título "Die Einwirkung der Sphaera barbarica auf die kosmischen Orientierungsversuche des Abendlandes. Franz Boll zum Gedächtnis" ["A influência da Sphaera Barbarica sobre as tentativas de orientação no Cosmos no 
Ocidente. Em memória de Franz Boll"] $]^{3}$ Warburg refere-se a Ludwig Geiger, que organizou e completou a obra de Jacob Burckhardt, Die Cultur der Renaissance in Italien, a partir da terceira edição (Leipzig, 1877-1878), como "um douto estudioso e comentador que o mestre aprecia". (Warburg, 2018: 176, grifo nosso) Burckhardt é reputado, então, como "um guia" ou como "o mestre" (der Meister). E esta é uma imagem que se fazia presente na mente de Warburg ainda nos últimos anos de sua vida.

Porém, malgrado a imagem de Burckhardt ter percorrido toda a trajetória intelectual de Warburg como a de um mestre que indica o caminho a ser trilhado e que abre, tal qual um guia, o campo a ser desbravado, há uma etapa da obra de Warburg em que o historiador suíço se faz presente de modo mais intenso. Trata-se do período dos estudos warburguianos sobre arte e cultura em Florença na segunda metade do século XV, que coincide com a fase final da produção de Jacob Burckhardtt. Burckhardt tinha retomado, em 1885, suas anotações sobre a pintura italiana no Renascimento, com intuito de dar uma forma final aos estudos sobre o tema, compondo, a partir de então, uma série de manuscritos. Warburg, que havia chegado à Universidade de Bonn em 1886, partira para Florença em 1888 para seguir os seminários de August Schmarsow, com o objetivo de elaborar o projeto da tese que defenderia em 1892 em Estrasburgo, sob orientação de Hubert Janitschek. Observemos mais detalhadamente este contexto.

Em 1860, quando Burckhardt decide editar $A$ Cultura do Renascimento na Itália, ele deixa claro que 0 projeto era apresentado ao público antes de conter sua forma final. Já na primeira página vinha declarado que o livro continha uma lacuna: faltava uma obra especial, consagrada à "Arte do Renascimento", que ali se apresentava apenas em parte (Burckhardt, 1978: III, 1). Portanto, a síntese histórico-cultural do Renascimento italiano, propósito do livro de 1860, pôde ser realizada apenas parcialmente, visto que, para seu autor, a arte representava uma das potências ativas na conformação da época histórica. A lacuna, então, transformava-se imediatamente numa dívida íntima, a qual 0 historiador por anos cultivaria como uma tarefa auto-imposta. Durante décadas, ainda que tenha se voltado a projetos distintos, a conclusão da síntese histórico-cultural do Renascimento na Itália, foi uma meta perseguida. No entanto, completar o livro de 1860, com uma obra consagrada à arte do Renascimento demandava reunir um vasto volume documental de textos e de obras de arte. Mas não apenas isso. Era preciso encontrar uma abordagem historiográfica que restituísse ao objeto artístico 0 seu lugar e o seu papel na história da época, compreendendo sua peculiar força dinâmica de testemunho histórico.

O primeiro fruto desse esforço, único editado em vida, veio a público em 1867 (reeditado em 1878) e tratou da arquitetura do Renascimento. Intitulado originalmente Geschichte der Renaissance in Italien: Architektur [História do Renascimento na Itália: arquitetura], o livro apresentava, já em suas primeiras linhas, o modo como Burckhardt buscava compreender a integração dos monumentos arquitetônicos com as demais forças históricas. Em suas palavras: "A arquitetura italiana, desde o despertar da cultura mais alta, é substancialmente condicionada pela mentalidade individual do comitente e do artista, que aqui se desenvolve muito antes que em outros lugares" (Burckhardt, 1978: II, 3). Burckhardt compreendia a fundamental relação entre comitente e artista como potência central na elaboração da obra de arte na Itália renascentista, relação que se colocava no cerne do processo criativo e que, por sua própria natureza, representava indissoluvelmente uma conexão entre arte e cultura. 0 comitente era entendido, assim, como figura de centro no mundo da arte, partícipe do processo criativo. Mais adiante, no mesmo volume, ele afirma: "Há casos em que, ou por iniciativa dos Príncipes ou por livre acordo, séries inteiras de edifícios ou ruas, tiveram uma decoração contínua pintada" (Burckhardt, 1978: II, 256). A decisão conjunta de artista e comitente sobre a pintura das fachadas era apenas um exemplo de que esse acordo era parte integrante dos projetos sobre os quais os artistas trabalhavam conferindo- 
Ihes forma final. Portanto, em 1867, quando concebe o volume sobre arquitetura, Burckhardt já apresenta o comitente como um personagem importante no processo criativo no Renascimento.

O estudo histórico-artístico assume o status de sistematicidade no trabalho de Jacob Burckhardt a partir de 1874, ano em que inaugura e assume a cátedra de História da Arte na Universidade de Basiléia. $\mathrm{Na}$ aula inaugural da disciplina, o problema da compreensão da arte na história é por ele reiterado:

Nós sentimos a arte como um fenômeno histórico de primeira grandeza, como uma potência ativa em nossa vida. Ela apresenta suficientemente aspectos tangíveis que permitem apreendê-la: suas manifestações monumentais estão estreitamente ligadas à história dos povos, das religiões, das dinastias e das civilizações. Sua dimensão técnica é indissolúvel de todas as outras técnicas do mundo. (E Plínio começou mesmo a descrevêla sob esse aspecto, evocando as matérias) Quanto ao lado biográfico, ela preenche sozinha bibliotecas inteiras (Burckhardt, 2010: 182).

Os "aspectos tangiveis" que permitem apreender a obra de arte como um "fenômeno histórico de primeira grandeza", professados por Burckhardt na aula inaugural, são o ponto nevrálgico do projeto de estudo da pintura italiana do Renascimento, que o historiador desenvolverá a partir de 1885. Como dissemos anteriormente, esta fase do trabalho de Burckhardt coincide com os anos de estudos acadêmicos de Warburg em Bonn e Florença, com a apresentação da tese sobre as pinturas mitológicas de Sandro Botticelli na Universidade de Estrasburgo e com as investigações sucessivas sobre arte e burguesia florentina, com foco ainda nas relações entre comitentes florentinos e arte flamenga na segunda metade do Quattrocento.

O primeiro texto de Jacob Burckhardt sobre a pintura italiana no Renascimento jamais chegou ao conhecimento de Aby Warburg, visto que o manuscrito permaneceu inédito e quase desconhecido até 1992, quando é publicado na Itália pelo trabalho de tradução e organização de Maurizio Ghelardi, que o intitulou Pittura: i generi (Burckhardt, 1992). Este texto é editado posteriormente na Alemanha com o título Die Malerei nach Inhalt und Aufgaben [A pintura segundo o conteúdo e as tarefas] (Burckhardt, 2006). O título na edição alemã é tomado da menção feita por Burckhardt de que naqueles anos desenvolvia uma pesquisa sobre a arte renascentista italiana "nach Inhalt und Aufgaben" [segundo o conteúdo e as tarefas]. De acordo como Ghelardi, é provável que o manuscrito tenha sido elaborado entre 1885 e o início de 1893, com exceção do último capítulo, sobre a pintura dos animais, concebido provavelmente em 1895 (Burckhardt, 1992: XVIII-XIX).

Investigar a pintura italiana do Renascimento segundo o conteúdo e as tarefas significava, para Burckhardt, abordar o material pictórico da época de acordo com uma dupla organização, que considerava o tema tratado na obra e sua localização original. O historiador pretendia com isso observar em que locais determinados temas eram solicitados e, paralelamente, compreender o desenvolvimento formal das obras no arco temporal do Renascimento. Portanto, a organização dos capítulos do manuscrito obedecia à lógica das temáticas pensadas para determinadas localizações originais. No interior de cada capítulo, o historiador procurava perceber o desenvolvimento formal das obras no correr do tempo. Assim, sua abordagem dava conta conjuntamente da função das obras de arte em seus contextos culturais, ao mesmo tempo em que não negligenciava o complementar aspecto formal das pinturas. Desse modo, o escrito é organizado em capitulos, tais como: Alegoria; A pintura dos conventos; A pintura dos hospitais; As irmandades5; Orbis terrarum (a pintura dos mapa-mundi); A pintura histórica profana; A pintura mitológica; entre outros. É significativo o que afirma Burckhardt no início do capítulo sobre as irmandades: 
As irmandades, companhias, scuole foram uma das grandes razões que tornaram possivel a atividade artística no século XV. (...) Obviamente, uma irmandade encomendava e colecionava de maneira diferente de um convento e de uma igreja, visto que não tinha nenhuma intenção de abrir mão daquele caráter precípuo que a tinha constituído e que se mantinha graças à sua tradição (Ibidem: 323 ).

Aqui fica claro o interesse em compreender as irmandades como uma potência ativa no mundo da arte na Itália do século XV, considerando o papel dessas associações na encomenda das obras e, portanto, pelo menos na decisão sobre o tema das mesmas. Até que ponto os dirigentes das irmandades discutiam com os artífices sobre aspectos formais dessas obras permanece, para Burckhardt, como uma incógnita. Com relação ao tema destinado a determinados locais, no capítulo "As pinturas nos hospitais" pode-se ler:

Os temas das pinturas das irmandades, principalmente as obras de beneficência, coincidiam com aqueles dos hospitais, visto que as pinturas não se limitavam apenas às representações da cura dos doentes, mas representavam de maneira monumental também outras atividades públicas. (Ibidem: 328 )

De todo modo, Die Malerei nach Inhalt und Aufgaben inaugurava, na obra de Burckhardt, uma abordagem da pintura italiana do Renascimento, ao mesmo tempo em que dava uma resposta ao problema com o qual ele se debatia havia mais de duas décadas, qual seja, aquele da indagação da arte no âmbito da história da cultura. Organizar a pintura italiana do Renascimento a partir do tema das obras e de sua localização original permitia-lhe primeiramente um diálogo com o plano sobre o qual tinha construído $A$ Cultura do Renascimento na Itália, seguindo uma ordenação narrativa que unia sincronia e diacronia. Na estrutura geral do livro de 1860, ele seguiu um arco temporal mais ou menos delimitado entre a vida de Dante e o Saque de Roma, e, no interior desses limites, sua visão percorreu o desenvolvimento da poesia, da narrativa historiográfica, da biografia, da autobiografia, do desenvolvimento cientííco, das descobertas marítimas, da vida religiosa, das construções políticas, etc. Sua ideia era, com isso, apresentar a vida na Itália do Renascimento tal como se apresenta uma imagem, dando portanto ao leitor a noção de simultaneidade.

Mais de vinte anos depois, o manuscrito sobre a pintura seguia de perto essa organização, apresentando a arte pictórica no centro da interpretação, dividida, ela também, a partir do duplo critério, sincrônico e diacrônico. Tal abordagem permitia a Burckhardt demonstrar em que medida a análise sincrônica das formas pictóricas podia ser exposta e explicada diacronicamente. Desse modo, a pintura italiana do Renascimento era interpretada com base num registro duplo e complementar: de um lado, por meio de uma reconstrução morfológica que buscava revelar as mudanças dos temas representados e as tarefas que $o$ artista tinha sido chamado a cumprir; por outro lado, mediante funções que estavam presentes num dado contexto cultural (Fernandes, 2013).

No momento em que Burckhardt elaborava o manuscrito sobre a pintura segundo o conteúdo e as tarefas, chega-lhe às mãos a cópia de um texto de Aby Warburg. Tratava-se da tese que jovem pesquisador havia recém-apresentado na Universidade de Estrasburgo: O Nascimento de Vênus e a Primavera de Sandro Botticelli. A tese, publicada em 1893, versava sobre o movimento das vestes e cabelos nos personagens dos dois painéis de Botticelli, pintados para ornar o salão de discussões na Academia Platônica de Florença [figs. 1 e 2]. Na conferência autobiográfica de 1927, Warburg remonta ao contexto da tese:

A descoberta de que as duas figuras da perseguição (Zéfiro e Flora), na Primavera de Botticelli, eram trazidas diretamente dos Fastos de Ovídio (...), foi para mim decisiva para 
a escolha do tema de meu trabalho de Doutorado, o qual teve como argumento a intensidade do movimento externo sob o signo da Antiguidade.

A tudo isso se conectava inevitavelmente uma questão posterior, que necessitava um aprofundamento metodológico. De fato: eu devia tentar compreender se entre os contemporâneos de Botticelli existiam documentos, ou mesmo poesias, que pudessem indicar-me quem tinha sido o mediador deste douto modelo para um grupo da perseguição. Tratava-se, então, de uma abordagem que privilegiava a análise da obra de arte individual (Warburg, 2018: 40-41).

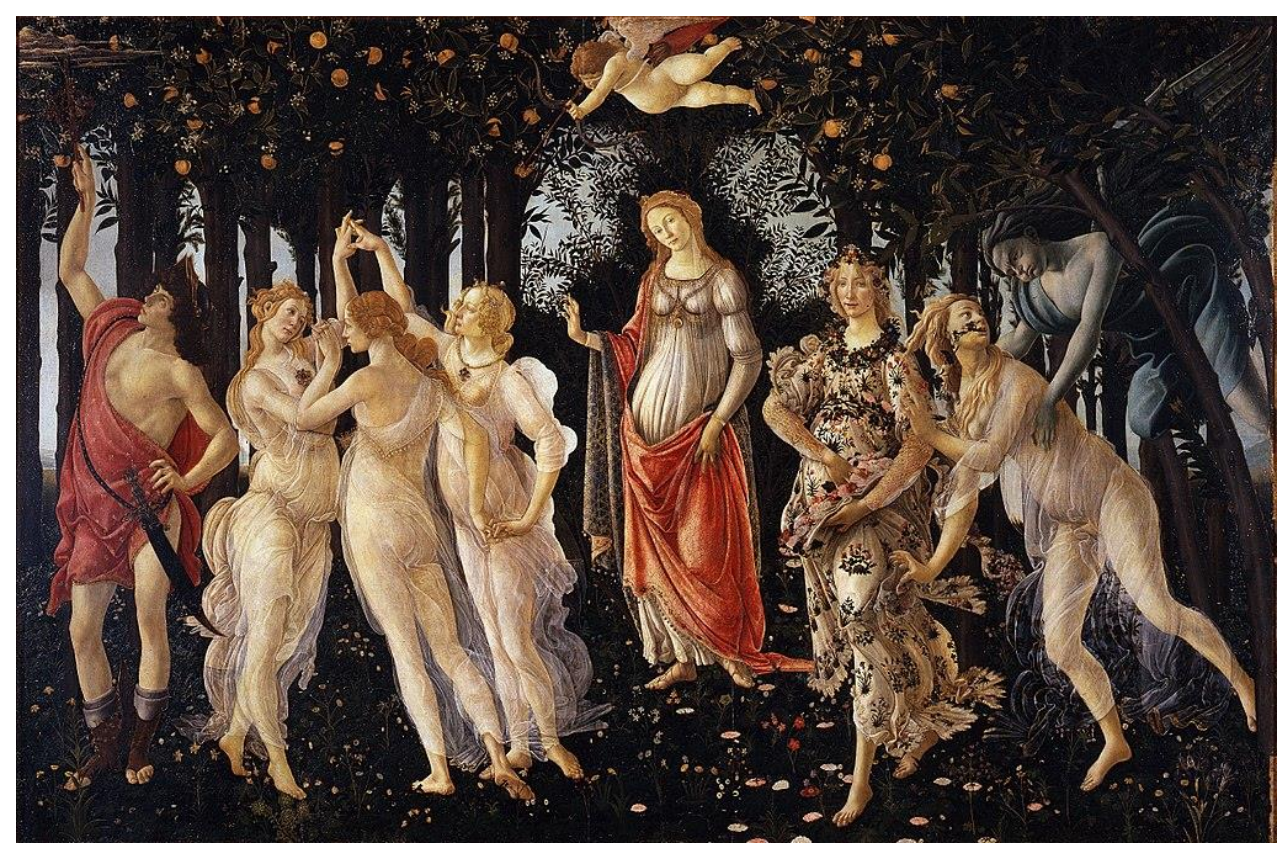

Fig. 1. Sandro Botticelli (1445-1510), Primavera, c.1482, têmpera sobre madeira, $203 \mathrm{~cm} \times 314 \mathrm{~cm}$, Galleria degli Uffizi, Florença. Fonte: <https://pt.wikipedia.org/wiki/A_Primavera_(Botticelli)>.

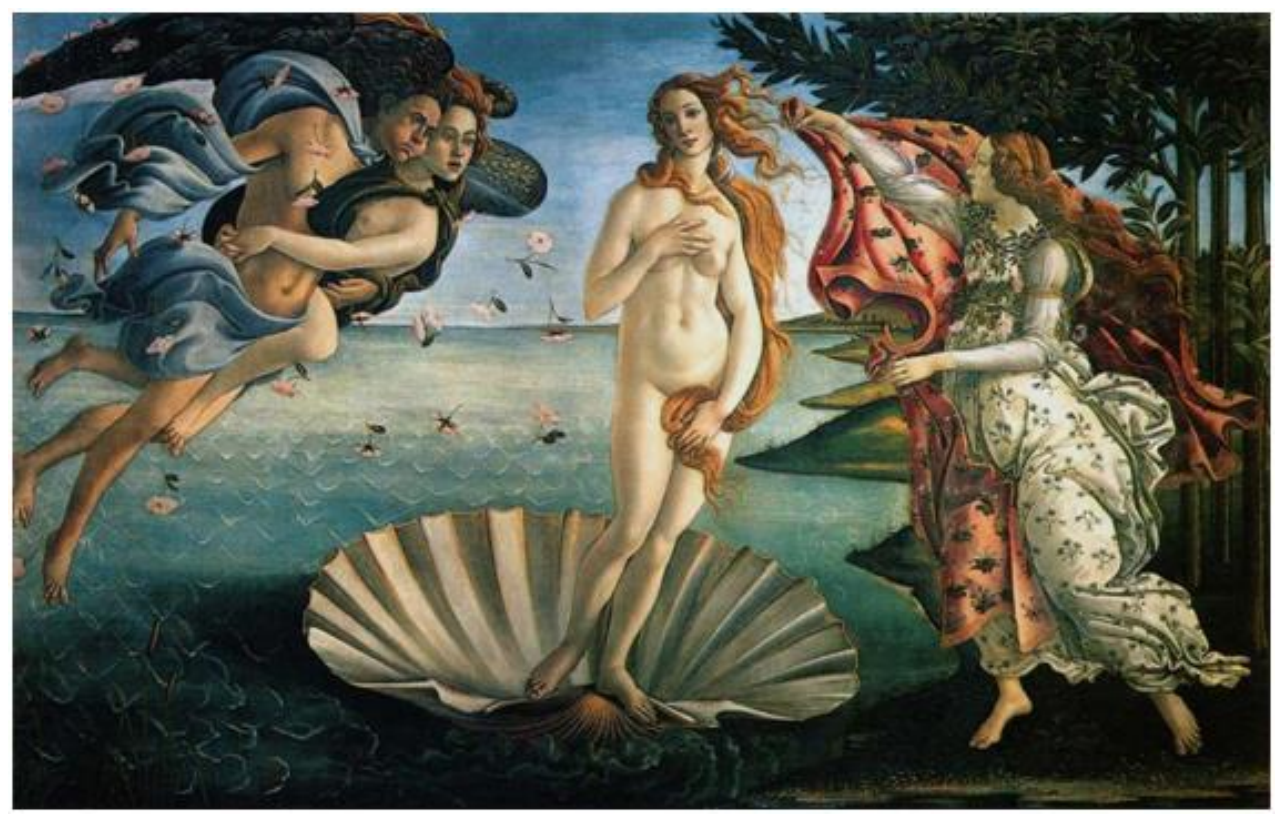

Fig. 2. Botticelli, Nascimento de Vênus, c.1484, têmpera sobre tela, $172.5 \mathrm{~cm} \times 278.5 \mathrm{~cm}$, Galleria degli Uffizi, Florença. Fonte: <https://pt.wikipedia.org/wiki/Ficheiro:Sandro_Botticelli__La_nascita_di_Venere_-_Google_Art_ProjectFXD.jpg>. 
Portanto, a tese continha o problema de cunho formal que no futuro Warburg denominaria "o ingresso do estilo ideal antiquizante na pintura do Primeiro Renascimento", que é título da conferência que profere em 20 de abril de 1914, no Kunsthistorisches Institut de Florença (Warburg, 2018: 91-140). Tratava-se de compreender o modo como o estilo all'antica, que assumirá caráter hegemônico na arte do Renascimento a partir do início do século XVI, apresenta-se já na pintura florentina das décadas finais do Quattrocento, porém ainda convivendo numa mesma representação com o estilo que Warburg denominava alla franzese, que apresentava uma atmosfera de placidez e serenidade nas feições e nos gestos das figuras representadas. Ou seja, no final do século XV, a representação dramática all'antica ao mesmo tempo em que promovia um ingresso na pintura florentina, convivia numa mesma obra com a serenidade que hegemonicamente marcava a figuração dos personagens nesse ambiente artístico ${ }^{6}$. Na tese, Botticelli (assim como Warburg observará no futuro também na obra de Domenico Ghirlandaio) era um representante dessa disputa entre dois estilos na arte florentina, disputa que precede a vitória do estilo all'antica do Alto Renascimento, como fica atestado nas obras de Michelangelo Buonarroti, de Giulio Romano e de tantos outros. Por isso as figuras de Zéfiro e Flora têm papel central na tese de Warburg. Zéfiro, por seu soprar, é o responsável por produzir o movimento das vestes e dos cabelos às figuras da representação. Flora é a ninfa que entra na figuração como o componente Antigo por excelência. Ambas as figuras dão à representação um movimento e uma tensão próprias da entrada em cena do elemento antiquizante. Portanto, a tese versou sobre os acessórios em movimentos nas figuras presentes nos dois painéis pintados por Sandro Botticelli, O Nascimento de Vênus e a Primavera. Paralelamente, como afirma Warburg na citada conferência de 1927:

Consegui descobrir que Poliziano, estudioso e poeta, tinha sido o mediador da passagem ovidiana. Em particular - coisa decisiva, para mim -, descobri que exatamente este douto humanista tinha sido quem transmitira os motivos antiquizantes à representação dramática (Warburg, 2018: 40-41).

Para Warburg, então, teria sido Angelo Poliziano o "mediador" entre o texto de Ovídio (base literária da pintura) e a representação de Botticelli ${ }^{7}$. Ou seja, a tese de Warburg propõe que o citado poeta e humanista florentino teria sido o idealizador do projeto iconográfico da obra de Botticelli, e que nesse diálogo entre poeta e artista cumprira-se a passagem da palavra para a imagem.

Warburg, assim, intuíra que sua tese deveria ter em Burckhardt um leitor fundamental, embora não pudesse saber que, no mesmo período em que estudava os painéis de Botticelli, o historiador de Basileia estava escrevendo o manuscrito sobre a pintura segundo o conteúdo e as tarefas. Em resposta à leitura da tese de Warburg, Burckhardt envia-lhe a carta de 27 de dezembro de 1892, na qual afirma:

Egrégio senhor,

o belo trabalho, que the restituo em postagem com os melhores agradecimentos, testemunha a extraordinária profundidade e poliedricidade alcançadas pela pesquisa sobre a época áurea do Renascimento. Com o seu escrito o senhor fez cumprir um grande passo adiante no conhecimento do medium social, poético e humanístico no qual Sandro [Botticelli] vivia e pintava (Burckhardt, 1993: 207).

Mesmo considerando que o percurso intelectual de Warburg apresentava-se aqui ainda em fase inicial, era já possivel perceber entre ambos os historiadores semelhanças no modo de observar a obra de arte como testemunho concreto, portador de um significado simbólico compreensível somente se indagado no mais vasto campo da cultura. A operação científico-cultural proposta por Warburg para a compreensão das pinturas de Botticelli remontava ao movimento interpretativo proposto pela abordagem histórico-artística de Burckhardt. 
No entanto, a organização proposta em Die Malerei nach Inhalt und Aufgaben não seria a última versão dada por Burckhardt ao estudo da arte pictórica renascentista. Em seguida à elaboração desse manuscrito, ele retoma o vasto material sobre o tema, reordenando-o e aprofundando sua abordagem histórico-artística, o que permite compreender o caráter experimental de sua pesquisa. Entre maio de 1893 e dezembro de 1895, escreve três novos manuscritos a partir de uma organização distinta, aos quais dá os seguintes títulos: "Das Altarbild" [O retábulo de altar], "Das Porträt in der italienischen Malerei" [O Retrato na pintura italiana] e "Die Sammler" [Os colecionadores]. Esse grupo de textos, elaborados após a leitura da tese de Warburg (tese que aparece citada mais de uma vez nos referidos manuscritos), será publicado postumamente em 1898 num volume único, organizado por Hans Trog (ex-aluno de Burckhardt e professor de história da arte em Zurique) sob o título Beiträge zur Kunstgeschichte von Italien [Contribuições à história da arte na Itália]. Uma nova edição desse volume foi realizada no âmbito do projeto editorial das obras completas do historiador suíço (Burckhardt, 2000).

A abordagem histórico-artística apresentada nos três manuscritos, reveladora da derradeira análise empreendida por Burckhardt sobre a arte italiana do Renascimento, concentrava-se no conhecimento material das obras, privilegiando os meandros de sua produção e destinação. Compreendendo, de modo geral, os elementos intrínsecos ao processo criativo naquele contexto histórico, Burckhardt traz para o centro de sua indagação as forças que concorriam nas várias etapas desse processo. Ciente de que a arte do Renascimento não é produto da decisão e do trabalho unilaterais do artista, o historiador suíço concede um novo protagonismo à comitência e ao colecionismo artístico nesse sistema produtivo. Era uma maneira de se aproximar do mundo dos artistas, ou seja, das peculiaridades do trabalho nas oficinas e da relação dos artífices com a comitência, incluído aí, muitas vezes, o papel dos conselheiros eruditos na composição do plano da obra e mesmo na constituição da iconografia.

Nesse aspecto, é importante determo-nos em algumas passagens presentes no volume sobre Os Colecionadores [Die Sammler] (Fernandes, 2016b: 47-60). Logo de início, Burckhardt afirma seu propósito no livro:

O capítulo de história da arte italiana que aqui tem início é muito mais amplo e importante do que se possa pensar. Por decênios, o peso maior da produção artística - não tanto pela quantidade, quanto pelo significado interno - devia à comitência e à possessão privadas. (...) Assim, tudo o que era encomendado pela casa e oferecido à consideração próxima e atenta de numerosas famílias, reivindicava uma execução totalmente particular. De tal modo, formou-se progressivamente um gosto privado que exigia da arte propriamente aquilo que a comitência pública não podia, nem queria garantir (Burckhardt, 2000: 291).

Burckhardt tem clareza quanto ao caráter pioneiro de seu estudo. Nesse texto, de fato, ele atenta para a necessidade de pensar a obra de arte no Renascimento como produto de um acordo entre comitente e artista. Ele pretende compreender o processo de realização das obras sugerindo os meandros das tomadas de decisão no momento de sua idealização. Ainda que na maioria das vezes fosse difícil reconstituir esse processo, o historiador, entretanto, fazia-se a pergunta: "Mas, quem decidia sobre 0 gênero da execução? Em Urbino, era o Duque Federigo da Montefeltro ou alguns artistas?" (Ibidem: 344). Na verdade, Burckhardt pretendia perceber, no processo criativo, não apenas os elementos concernentes à biografia dos artistas ou aos estilos individuais, mas era fundamental para ele compreender como a mudança na forma era acompanhada de uma modificação análoga no gosto dos comitentes e dos colecionadores. 
O modo como ele define o teor de suas investigações histórico-artísticas da fase derradeira de sua vida ficara atestada na passagem de uma conferência de Heinrich Wöfflin, seu ex-aluno e sucessor na cátedra de História da Arte na Universidade de Basiléia. Wölfflin narra que, em seu septuagésimo quinto aniversário, reunido com um pequeno grupo de amigos, Jacob Burckhardt, com ar solene e conciso, declara: "Die Kunst nach Aufgaben, das ist mein Vermächtnis" [A arte segundo as tarefas, eis o meu legado] (Wölfflin, 1946: 143). Com a frase, o historiador pretendeu revelar exatamente o interesse em compreender a arte italiana do Renascimento de acordo com a origem das comitências e com seu papel na idealização das obras.

De todo modo, o volume de 1898, Beiträge zur Kunstgeschichte von Italien exerce imediatamente grande fascínio em Aby Warburg, impactando seu trabalho nos anos seguintes. O próprio Warburg, na conferência de 1927, afirma que "a partir de 1897" assume "como tarefa científica (...) considerar a obra de arte como produto estilístico de um entrelace com a dinâmica da vida, em sentido mais amplo" (Warburg, 2018: 41). De fato, em 1897, ele se estabelece em Florença, e ali permanece, pelo menos durante os meses de inverno, até janeiro de 1902. Planeja a elaboração de um livro que, no entanto, jamais seria finalizado, embora as investigações dessa fase ficassem atestadas em algumas publicações. Nesse período, o contato com a obra de Burckhardt é fundamental e ele assim o declara em várias oportunidades. Em junho de 1900, em carta ao irmão Max, em Hamburgo, Aby Warburg explica o teor de sua pesquisa, pede recursos financeiros maiores para a compra de livros e afirma 0 seguinte ao final: "Se algum dia meu livro aparecer mencionado em relação e como complemento à Cultura do Renascimento de Jacob Burckhardt, será uma compensação que você e eu teremos" (apud Gombrich, 1992: 129).

Sobretudo dois dos três manuscritos burckhardtianos publicados no livro de 1898 serão de relevante importância para as investigações de Warburg dessa fase: Das Porträt in der italienischen Malerei [0 Retrato na pintura italiana] e Die Sammler [Os colecionadores].

No escrito sobre os colecionadores, Burckhardt havia indicado o papel da pintura flamenga para 0 desenvolvimento do colecionismo artístico em Florença. Percebera que as fontes primordiais de todas as coleções artísticas na Itália foram determinadas, de início, pelo acúmulo de quadros para devoção doméstica, que serviam de consolo e conforto, dispostos sobretudo nas casas abastadas. Afirma que essas obras eram objeto da devoção mais profunda e que, num primeiro momento, consistiam em exemplares da pintura bizantina, mantidas sob possessão das famílias por legado. No inventário de Cosimo de' Medici, morto em 1464, são citadas doze pinturas bizantinas de representações sacras, ornadas em ouro, prata, pedras preciosas e mosaicos, provavelmente oriundas da Grécia, e certamente para finalidade de devoção particular (Fernandes, 2016b: 55).

Contudo, com base no estudo do inventário dos Medici, Burckhardt percebe que por intermédio dessa família, no Quattrocento, nasce em Florença um colecionismo originado não apenas do legado familiar, mas também de aquisições e, não raro, por encomenda. Destarte, na Florença dos Medici do século $\mathrm{XV}$, somam-se à ideia da coleção privada as tarefas de colecionador e comitente, em grande parte motivadas pelo gosto da burguesia local em favor da pintura flamenga. Burckhardt observou o gosto privado do colecionador como uma das "tarefas" (Aufgaben) que tornaram possível à arte 0 aprofundamento de temáticas devocionais e a valorização de novos temas profanos. Para ele, 0 colecionismo no Renascimento constitui um dos fatores principais da escolha de conteúdos artísticos, a ponto de interferir diretamente no aspecto formal das obras. Era fundamental, então, compreender de que modo a mudança na forma vinha acompanhada de uma modificação análoga no gosto dos comitentes e dos colecionadores. Foi importante, naquele ínterim, a edição do livro de Eugène Müntz a 
respeito das coleções dos Medici no século XV (Müntz, 1888). Os inventários dos Medici confirmavam a primazia da relação entre "tarefa" (Aufgabe) determinada pelo colecionador e "conteúdo" (Inhalt) de uma obra. Aqui conectavam-se os elementos primordiais para que o historiador suíço pudesse perceber as características do processo criativo na arte florentina, em outras palavras, relacionavam-se colecionismo e comitência como forma de expressão do gosto privado, atuando na realização das obras. Burckhardt havia concluído que os flamengos tinham determinado o desenvolvimento do primeiro colecionismo italiano, sobretudo pela capacidade realística que a pintura a óleo, desenvolvida em Flandres, passou a permitir, mas também pela circulação dos produtos têxteis, tapetes e quadros flamengos de pequenas dimensões, movimento de objetos que antecede a circulação dos artistas nórdicos, propriamente, em direção à Itália (Fernandes, 2016b: 55-56).

Remontando ao período da viragem do século XIX para o XX, Aby Warburg, na conferência autobiográfica de 1927, refere-se ao colecionismo entre os Medici e sua predileção pelos objetos artísticos oriundos no Norte europeu:

Imaginando que no Palácio Medici devia existir cerca de 250 metros de tapetes representando em parte modelos antigos ou italianos, convenci-me de que era necessário compreender concretamente esta gigantesca trama figurativa. (...) Porque naqueles anos, vagueando entre a Alemanha e a Itália, inseguro sobre onde me estabelecer, tive diante dos olhos um único problema: o fenômeno das trocas entre as culturas do Sul e do Norte, que tinha surgido em mim de modo veemente (Warburg, 2018: 45-46).

Warburg remete, então, a uma importante fonte para os estudos de Burckhardt sobre o tema do colecionismo no âmbito da burguesia florentina: "O inventário dos Medici, que Müntz tinha publicado até então apenas em parte ${ }^{8}$, tornou-se uma nova fonte de conhecimento" (Warburg, 2018: 45). De fato, em 1901, valendo-se da edição de Eugène Müntz, Warburg produz um texto curto intitulado "Flandrische und florentinische Kunst im Kreise des Lorenzo Midici um 1480" [Arte flamenga e florentina no círculo de Lorenzo de' Medici por volta de 1480] (Warburg, 1932: 207-212). Nas primeiras linhas, faz referência a Burckhardt: "O tema da influência da arte flamenga sobre a Itália foi abordado de forma pioneira por Jacob Burckhardt, que, em traços gerais, reuniu os dados individuais e caracterizou seu desenvolvimento" (Ibidem: 209). Concentrando-se em particulares obras de arte flamengas do final do século XV, Warburg empreende uma pesquisa arquivística com o intuito de decifrar, com base em documentação, os personagens representados nas cenas, definir questões relativas à comitência $e$ datação, e estabelecer possíveis influências da pintura flamenga sobre obras pictóricas italianas da mesma época. O historiador concentra-se na sucessão cronológica dos representantes do banco dos Medici em Bruges, com a finalidade de decifrar possíveis comitentes retratados nas cenas pintadas. Procede do mesmo modo com relação à data dos matrimônios desses sócios dos Medici em Flandres, bem como com o ano de nascimento de seus filhos, visto que era costume a representação de famílias inteiras como doadores nas cenas sacras executadas por artistas flamengos.

Com esse breve estudo de caso, Warburg tem o propósito de compreender o intercâmbio cultural entre Florença e Flandres protagonizado pela arte da pintura, que adquire o papel de produto culturalmente híbrido, concretizado a partir da relação entre comitente florentino e pintor flamengo. Inicialmente, essa troca cultural se materializa em obras pictóricas como a Pala Portinari [Fig. 3], que o mercador florentino Tommaso Portinari tinha encomendado a Hugo van der Goes por volta de 1475, para a Igreja de Sant'Egidio, no Hospital de Santa Maria Nuova, em Florença. Esse exemplo servia para Warburg como emblema da relação direta entre gosto do comitente e execução artística. Num segundo momento, a poderosa influência da arte flamenga sobre aquela florentina revela um elemento a mais: os três 
pastores figurados na Pala Portinari [Fig. 4] teriam se tornado modelo direto para os três pastores da Adoração pintada por Domenico Ghirlandaio, em 1485, para ornar a capela encomendada por Francesco Sassetti (outro representante do banco dos Medici) na Igreja de Santa Trinità, em Florença [Fig. 5].
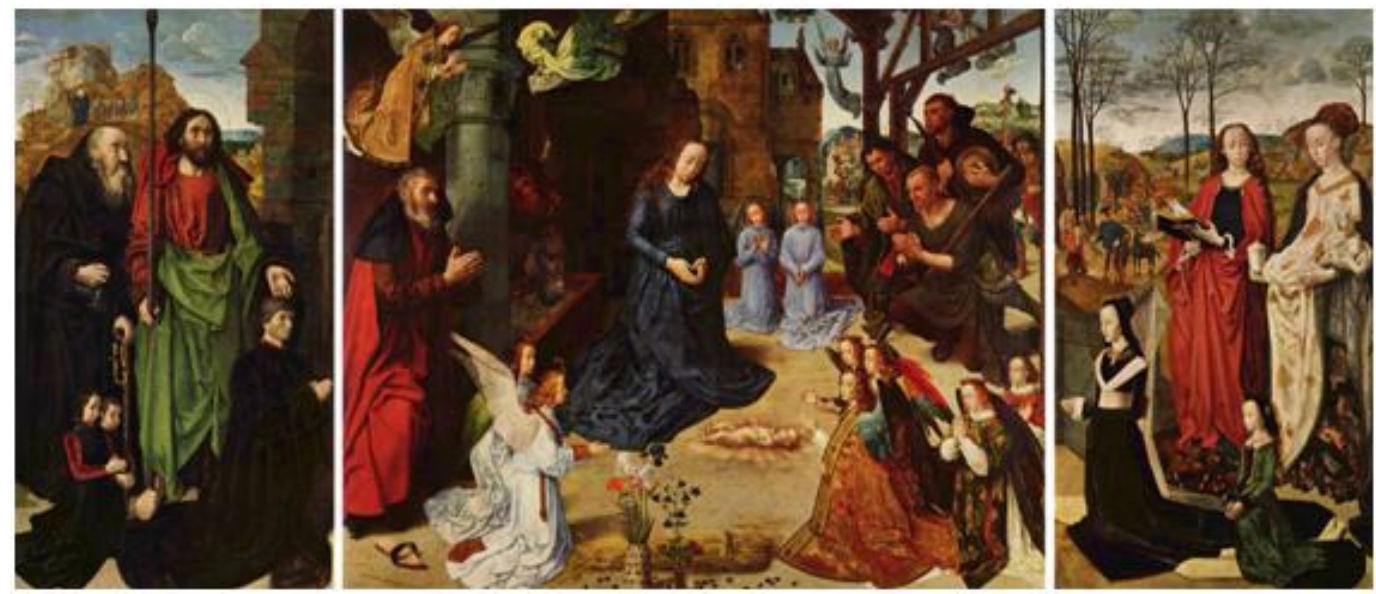

Fig. 3. Hugo van der Goes (1440-1482), Natividade (Pala Portinari), 1475, óleo sobre madeira, parte central: 253 x 304 cm; laterais: 253 x $141 \mathrm{~cm}$, Galeria dos Uffizi, Florença. Fonte: <https:/it.wikipedia.org/wiki/Trittico_Portinari>.

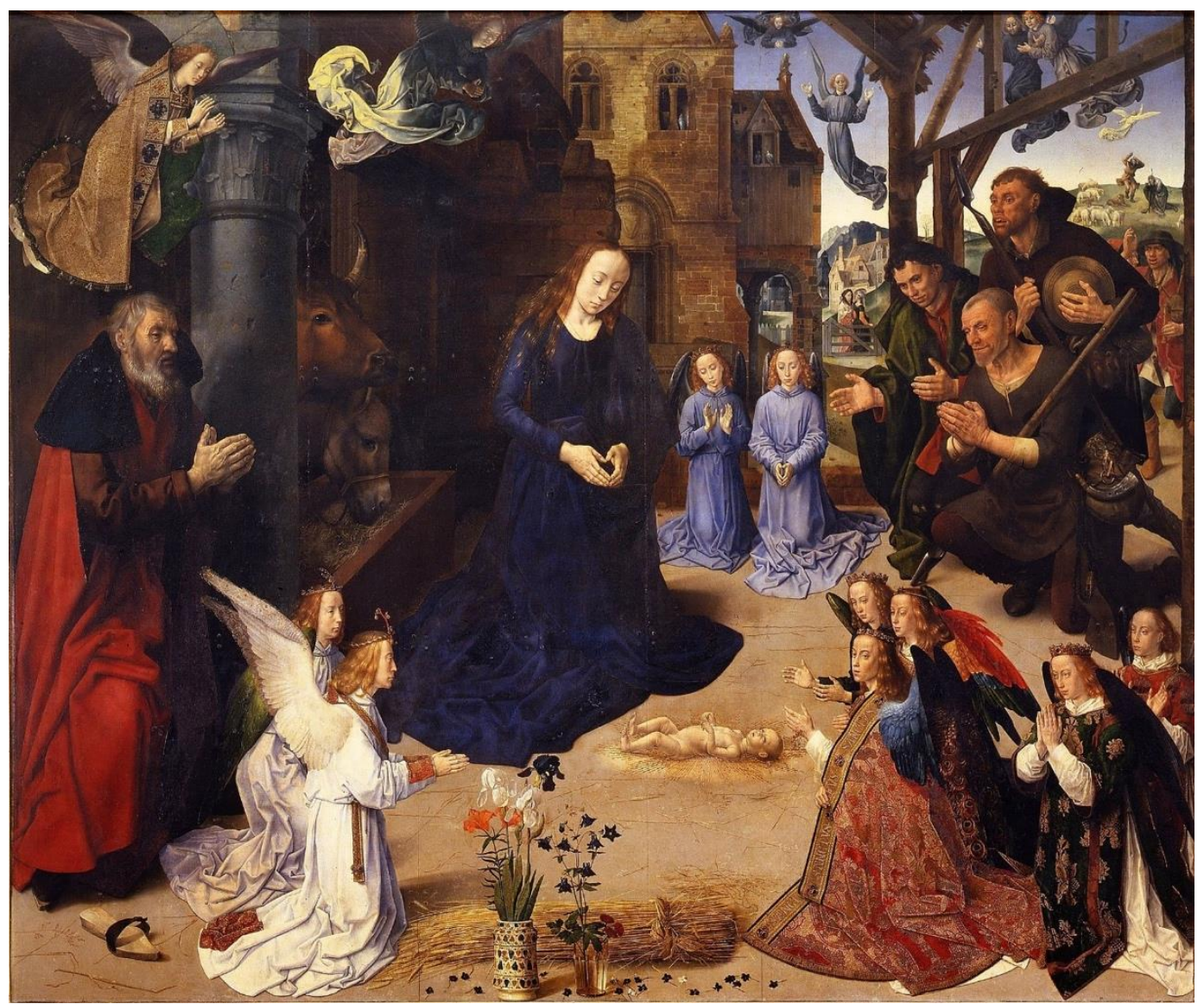

Fig. 4. Hugo van der Goes, Natividade (Pala Portinari) (detalhe), 1475, Galeria dos Uffizi, Florença. Fonte: <https://it.wikipedia.org/wiki/Trittico_Portinari>. 


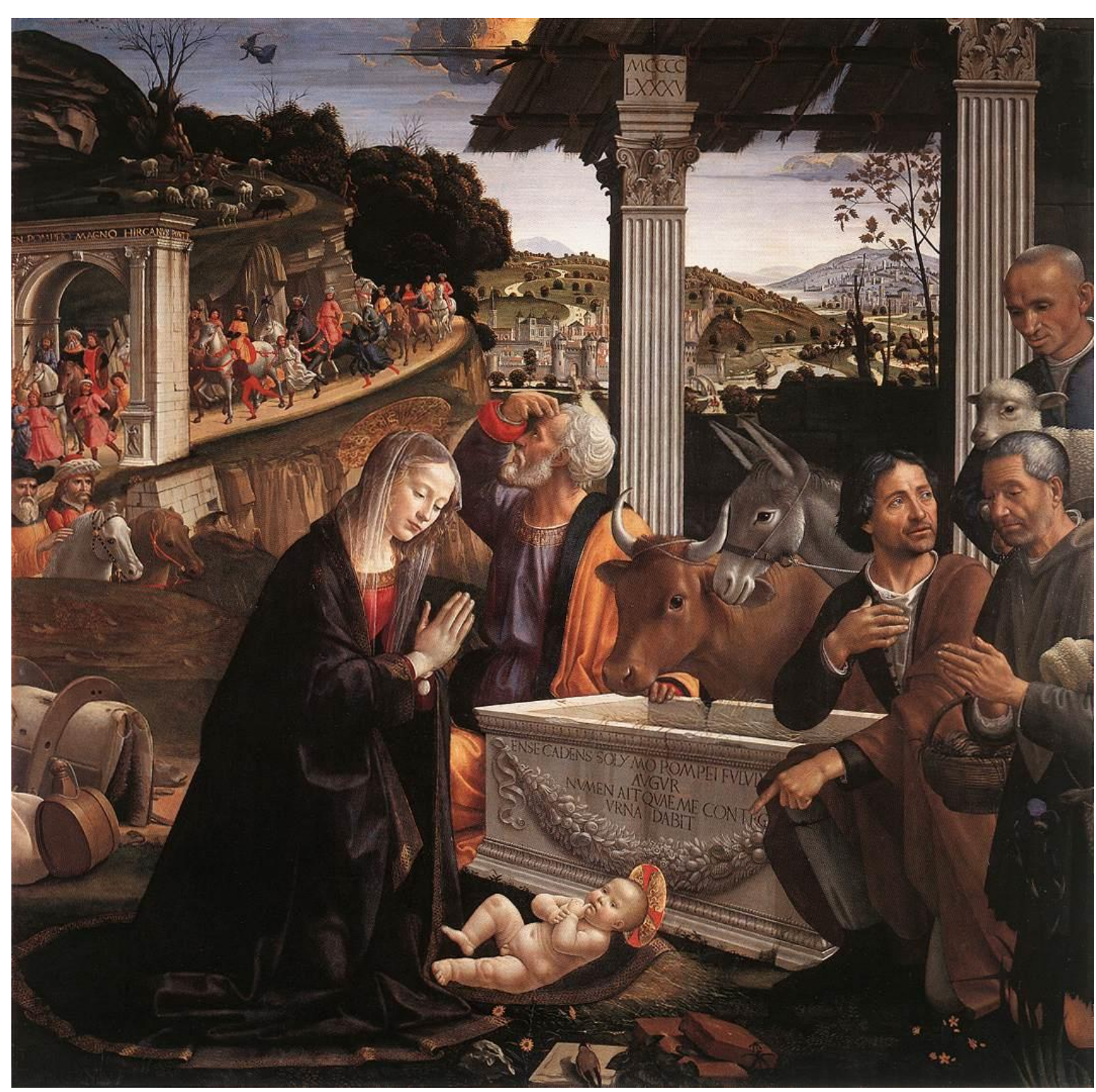

Fig. 5. Domenico Ghirlandaio (1449-1511), Adoração dos Pastores, 1485, afresco, 167 x $167 \mathrm{~cm}$, Capela Sassetti, Igreja de Santa Trinità, Florença. Fonte: <https://pt.m.wikipedia.org/wiki/Ficheiro:Adoration_of_the_Shepherds.jpg>.

No entanto, esta temática será desenvolvida pelo estudioso um ano depois, em 1902, num texto de elaboração mais detalhada: "Flandrische Kunst und florentinische Frührenaissance" [Arte Flamenga e Primeiro Renascimento Florentino] (Warburg, 1932: 185-206). Aqui novamente a obra dos últimos anos de Burckhardt se faz presente como ponto de partida. Warburg inicia o texto com uma menção, em nota de rodapé (Ibidem: 187), ao ensaio burckhardtiano sobre os colecionadores, para, então, desenvolver a argumentação a respeito do papel do colecionismo e da comitência como forças motrizes da arte renascentista. E, nesse contexto, interessa-lhe primordialmente a predileção, por parte de uma classe de burgueses florentinos amantes das artes, pelos produtos artísticos flamengos. É nesse processo que o colecionador florentino passa a encomendar os objetos flamengos para sua coleção particular. No entanto, como tivemos a oportunidade de observar em texto publicado anos atrás: 
Era importante, então, para Warburg, perceber o papel desempenhado pelo gosto do colecionador na concepção do quadro. Ele percebia que a expressão do artista flamengo dialogava com o gosto artístico do comitente italiano. Este comitente, impactado pelos meios de expressão da pintura flamenga aplicados sobre telas de pequenas dimensões, solicitava ao pintor o tema desejado e certamente requeria alguns elementos compositivos e formais de seu agrado, e dessa relação recíproca nascia a obra de arte para culto privado.

O interesse de Warburg em compreender as imagens como símbolos de circulações, de migrações de homens e de idéias, seu esforço em perfazer os caminhos das conexões, dos encontros entre elementos distintos, sua determinação em entender a fronteira como o próprio terreno da história, possibilitou-lhe perseguir as relações entre colecionismo italiano e arte flamenga (Fernandes, 2016b: 59).

Além da Pala Portinari (de Hugo van der Goes) [Fig. 3], que o historiador já havia tratado no texto de 1901, ele agora incluirá em sua análise das relações entre encomendante florentino e artista executor flamengo, entre outros, o famoso retrato do casal Arnolfini, obra de Jan van Eyck [Fig. 6], e o tríptico pintado por Memling para a Igreja de Santa Maria, em Gdansk, representando o Juízo Final, no qual os comitentes, o casal italiano Angelo Tani e Caterina Tanagli, são retratados de joelho na parte de trás dos painéis laterais [Fig. 7 e 8].

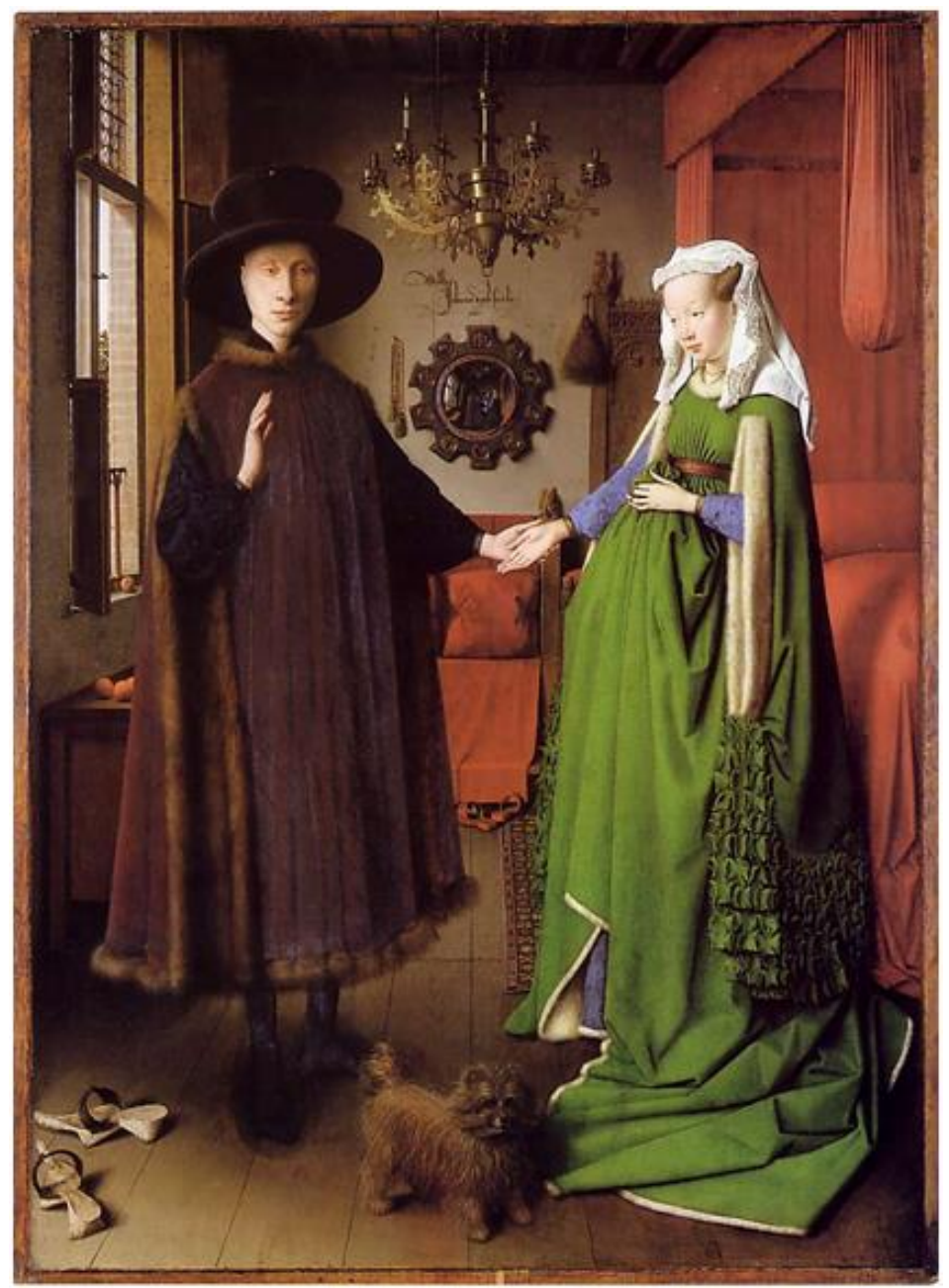

Fig. 6. Jan van Eyck (c.1390-1441), Giovanni Arnolfini e sua esposa (Casal Arnolfini), 1434, óleo sobre madeira, 81,8 x 59,7cm, National Gallery, Londres. Fonte: <https://pt.wikipedia.org/wiki/O_Casal_Arnolfini>. 


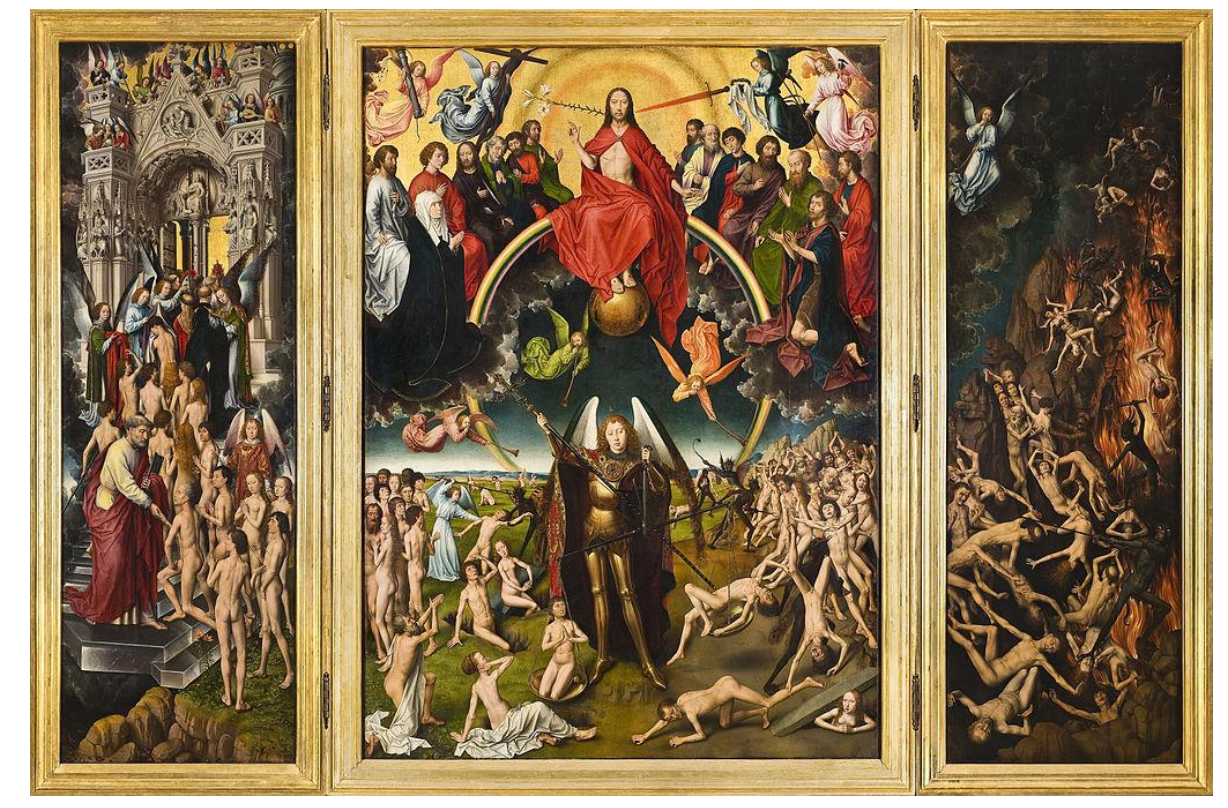

Fig. 7. Hans Memling (c.1390-1441),Juizo Final, 1467-1471, óleo sobre madeira, 306×222 cm, Museu Nacional de Gdansk. Fonte:<https://commons.wikimedia.org/wiki/Category:The_Last_Judgment_(Memling)\#/media/File:Das_J\%C3\%BCngste_Gericht_(Memling)

.jpg>.

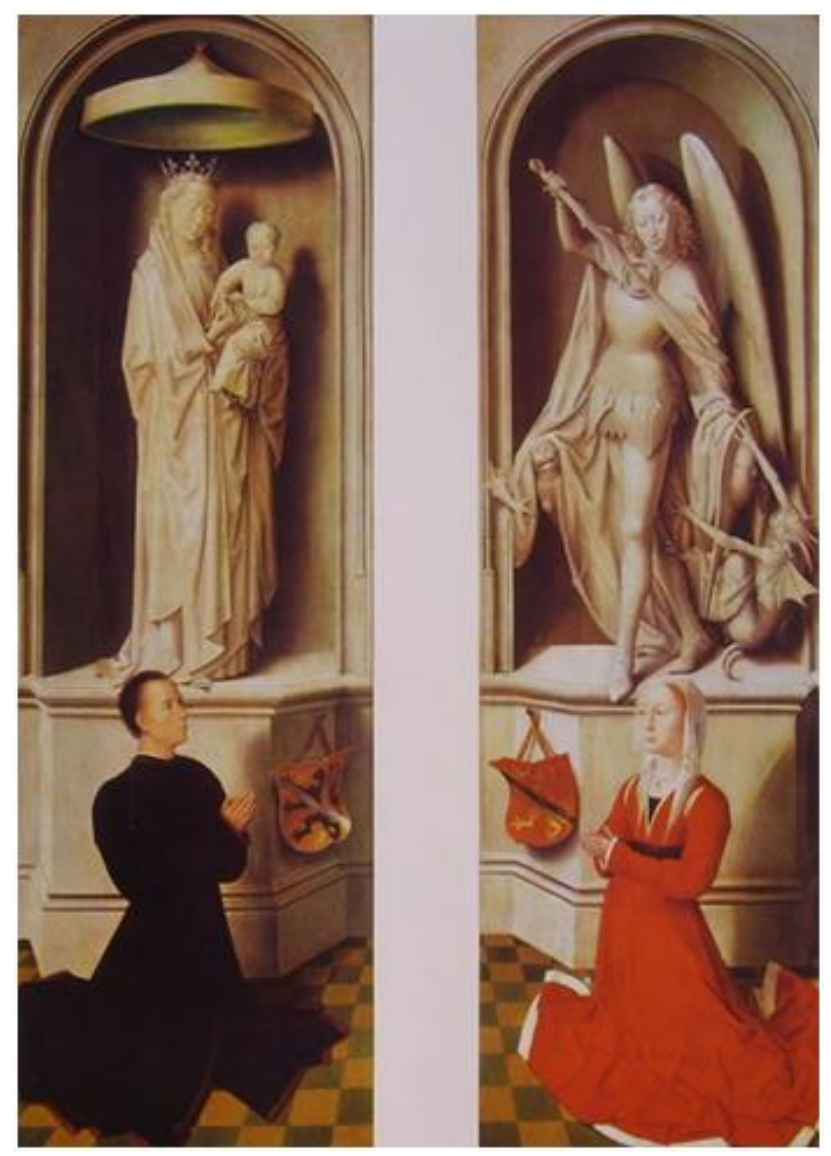

Fig. 8. Hans Memling, Angelo Tani e Caterina Tanagli, 1467-71, óleo sobre madeira, cada painel: $223,5 \times 72,5 \mathrm{~cm}$, Igreja de Santa Maria, Gdansk. Fonte: <https://pt.wikipedia.org/wiki/Lista_de_obras_de_Hans_Memling>. 
Porém, também no ano de 1902, Aby Warburg escreve Bildniskunst und florentinisches Bürgertum [Arte do Retrato e Burguesia Florentina] (Warburg, 1932: 89-126), texto no qual ressalta, numa longa dedicatória em forma de prefácio, sua posição de continuador da pesquisa da fase final da vida de Burckhardt. Desta vez o centro da discussão é outro manuscrito burckhardtiano editado também no livro de 1898: Das Porträt in der italienischen Malerei [O Retrato na pintura italiana].

Como pioneiro exemplar [afirma Warburg], Jacob Burckhardt abriu à ciência e dominou genialmente o campo da civilização italiana do Renascimento. (...) em suas póstumas Contribuições à história da arte na Itália, para aproximar-se da grande meta de sua síntese histórica daquela civilização, ele abriu ainda uma terceira via empírica: não desdenhou 0 esforço de indagar a obra de arte singular em seu nexo direto com o fundo da época para interpretar as exigências ideais ou práticas da vida real como "causalidade".

A nossa consciência da superior personalidade de Jacob Burckhardt não nos deve impedir de continuar pela via por ele indicada. Uma estadia de anos em Florença, estudos naquele Archivio, os progressos da fotografia, e a delimitação local e cronológica do tema encorajam-me a publicar no presente escrito uma nota ao ensaio burckhardtiano sobre "0 retrato" nas supra-citadas Contribuições à história da arte na Itália (Ibidem: 93-94).

Em O Retrato na pintura italiana, lançando um olhar de conjunto sobre o tema, Burckhardt havia proposto um estudo da representação da figura humana como retrato com base na mentalidade local e nas capacidades artísticas. Assim, o retrato pictórico, como uma das grandes expressões do homem do Renascimento, aparece em conexão com as tradições da arte da pintura em cada região da Península Itálica, bem como num diálogo com as demais formas expressivas de representação da figura humana em movimento. Para o caso florentino, por exemplo, a pintura de retrato é compreendida em paralelo às expressões literárias representadas pela biografia e autobiografia, que, de resto, tinham sido fundamentais para Burckhardt sustentar a tese central do livro com o qual construíra a síntese histórica do período, A Cultura do Renascimento na Itália. No manuscrito sobre o retrato na pintura do Renascimento, composto em 1895, a pintura de retrato em Florença surge da mesma base ideal em que se sustentavam as narrativas biográficas e autobiográficas, qual seja, o conceito de uomini illustri, difundido na cultura local pelo menos desde Filippo Vilanni (1848), do final do século XIV, como estrutura narrativa da história da cidade. Assim, ainda que promovesse uma visão de conjunto sobre o retrato na pintura italiana do Renascimento, Burckhardt não deixou de considerar como um dado primordial de sua pesquisa as diversidades regionais sobre as quais essa representação artística se assentou. 0 volume sobre o retrato enquadrava-se, então, no escopo da pesquisa, realizada no final de sua vida, com a qual pretendeu indagar a pintura do Renascimento italiano segundo "os temas e as tarefas" (nach Gegeständen und Aufgaben) e "os meios e as capacidades" (nach Mittel und Kräften).

Warburg parte desse conjunto de problemas trazidos por Burckhardt para empreender um estudo de caso: a análise de um retrato, pintado por Domenico Ghirlandaio para ornar a capela sepulcral da família Sassetti na Igreja de Santa Trinita, em Florença [Fig. 9]. Nesta cena em afresco, Ghirlandaio representa a confirmação da regra de São Francisco pelo Papa Honório III, tendo, em primeiro plano, uma série de personagens retratados como observadores da cena sacra. Trata-se de Francesco Sassetti, sócio do banco dos Medici, ladeado por seus filhos e por Lorenzo de' Medici, filhos e três literatos a ele ligados: Angelo Poliziano, Luigi Pulci e Matteo Franco. Ao lado de Sassetti há ainda um personagem que Warburg identificará apenas anos depois como Antonio Pucci. 


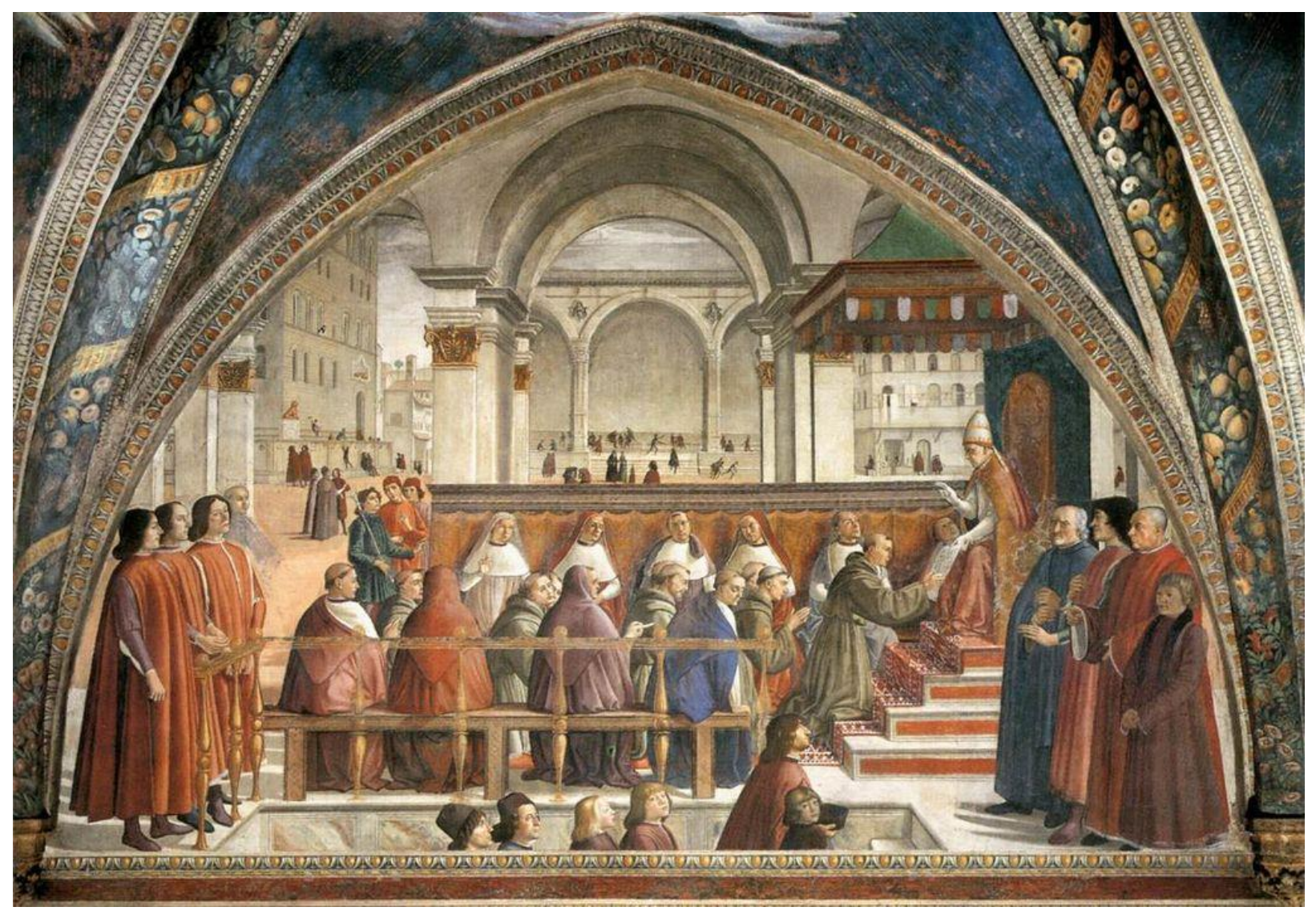

Fig. 9. Domenico Ghirlandaio, A Confirmação da Regra de São Francisco pelo Papa Honório III, déc. 1480, afresco, Capela Sassetti, Igreja de Santa Trinità, Florença. Fonte: <https://it.wikipedia.org/wiki/Cappella_Sassetti>.

Com os olhos voltados para o retrato em questão, Aby Warburg desenvolve um duplo movimento investigativo, muito sugestivo da indagação histórico-artística sobre um fundamento científico-cultural. De um lado, por meio da investigação sobre os personagens retratados na cena, ele pretende, mediante "prova indiciária" (Indizienbeweis), desvelar o universo mental do círculo mais próximo em torno de Lorenzo, o Magnífico, considerando ainda o emblemático personagem Francesco Sassetti, 0 encomendante da obra. Sassetti representa, para Warburg, o representante da laica burguesia florentina do início do Renascimento, com uma personalidade que congrega características completamente heterogêneas: do idealista cristão-medieval, cavalheirescamente romântico ou clássicoplatonizante, e do mercador prático à maneira etrusco-pagã, pragmático e voltado para o mundo. Tudo isso fundido na personalidade de Sassetti simboliza, para Warburg, um traço da psicologia representativa de um estrato social decisivo para os destinos de Florença na segunda metade do Quattrocento, seja no que se refere ao universo das artes e da cultura, seja no que diz respeito ao mundo político. Francesco Sassetti, com seu universo mental próprio, com sua procurada demonstração de proximidade com os Medici, é, nesse sentido, um personagem exemplar. Do mesmo modo, o retrato pintado por Ghirlandaio, ainda que entendido como expressão única, serve para desnudar a psicologia coletiva desse estrato social na Florença de Lorenzo, o Magnífico. 
Concomitantemente, Warburg pretende compreender 0 afresco de Ghirlandaio no contexto do desenvolvimento da pintura de retrato no Renascimento florentino. E utiliza, como comparativo, a mesma cena da confirmação da regra de São Francisco pelo Papa Honório III, pintado cerca de 150 anos antes por Giotto, na Capela Bardi, na Basílica de Santa Croce [Fig. 10]. Neste caso, os personagens retratados como observadores da cena sacra compõem-se de duas duplas de religiosos figurados do lado de fora do salão onde o episódio é representado. Entre a cena sacra e os personagens retratados há uma separação concebida pela arquitetura pintada, simbolizando a cisão inexorável entre dois mundos. De modo diverso, na pintura de Ghirlandaio, os retratados são não apenas representados no mesmo ambiente em que se dá a cena sacra, como estão colocados em primeiro plano e de costas em relação a ela. 0 episódio sacro é agora quase secundário em relação aos personagens do mundo laico ali figurados. Há, portanto, um certo destaque do retrato, como que fosse impulsionado para fora do cenário sagrado. É neste momento que a atenção de Warburg se volta para a interpretação da história do retrato pictórico em Florença. Porém, mesmo aqui o estudo propriamente histórico-artístico aparece vinculado a um diálogo com o fundo cultural, representado por uma psicologia coletiva expressa na localização e nos gestos dos personagens representados no afresco. $E$, numa velada referência a Burckhardt, o estudioso de Hamburgo concentra-se, nas linhas iniciais do texto, na importância do comitente como partícipe ativo no sistema de produção da arte:

As forças motrizes de uma arte viva do retrato não devem ser pesquisadas exclusivamente no artista; é necessário ter presente que entre retratista e retratado tem lugar um íntimo contato que numa época de um gosto especialmente refinado faz nascer entre os dois uma esfera de relações recíprocas, de freio e de impulso (Warburg, 1932: 95).

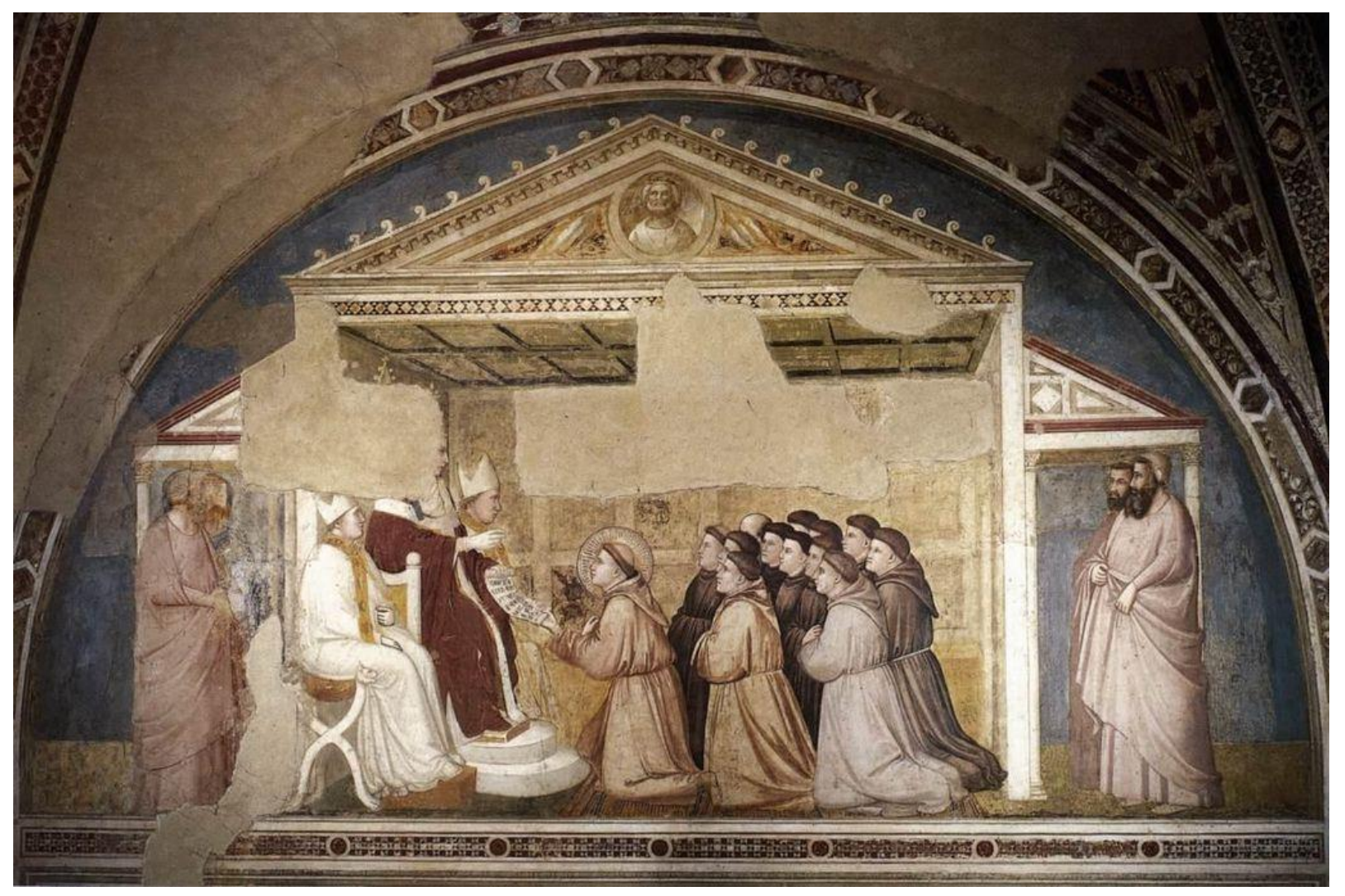

Fig. 10.Giotto di Bondone (1267-1337), A Confirmação da Regra de São Francisco pelo Papa Honório III, c.1325, afresco. Igreja de Santa Croce, Capela Bardi, Florença. Fonte: <https://it.wikipedia.org/wiki/Cappella_Bardi_(Santa_Croce)>. 
Uma continuidade a esse estudo seria dada por Warburg em 1907, com o belo ensaio "Francesco Sassettis letzwilligs Verfürgung" [O último desejo de Francesco Sassetti] (Ibidem: 127-158), no qual ele analisa a carta testamentária do personagem que havia sido retratado por Ghirlandaio em sua capela sepulcral. 0 testamento de Sassetti servia para Warburg aprofundar as questões sobre as quais se debruçara em 1902, como ele próprio aponta no texto de cinco anos depois:

Este documento lança luz sobre a psicologia do homem laico culto do início do Renascimento florentino, em nossa tentativa de compreender psicologicamente Francesco, tendo como base informações histórico-culturais contidas em seu último desejo (Ibidem: 130).

O ano de 1907 é, no entanto, um divisor de águas na obra de Aby Warburg. Este é o ano em que ele acessa pela primeira vez a obra Sphaera. Neue griechische Texte und untersuchungen zur geschichte der Sternbilder [Sphaera. Novos textos gregos e estudos para a história das constelações], do filólogo Franz Boll (1903) e, com isso, inicia uma nova fase em sua atividade intelectual, começando a investigar intensamente a história da mitologia e da astrologia, focalizando a descrição das divindades pagãs nos textos medievais e a continuidade do imaginário astrológico da Antiguidade nos tempos modernos, para se dedicar de modo sistemático aos estudos astrológicos. Com o tema da astrologia no centro de seu interesse, Warburg traz elementos novos à sua noção de Renascimento. Os intercâmbios culturais entre Norte e Sul, que sustentaram epistemologicamente seus estudos (inspirados em Burckhardt) sobre a relação entre arte flamenga e primeiro Renascimento florentino, não serão mais suficientes para enquadrar suas investigações sobre astrologia. A partir de 1907, com o foco voltado para o tema astrológico, os estudos de Warburg absorvem o vasto universo das interpretações árabes e indianas do mundo grego antigo, compreendendo, assim, um caminho migratório muito amplo a conectar 0 Renascimento italiano à Antiguidade grega. Era este um movimento de ampliação geográfica das circulações e transferências que abarcaram as questões relativas à vida póstuma da Antiguidade e, consequentemente, as conformações das imagens no Renascimento. Com tal expansão de fronteiras, Warburg toma certa distância em relação a Burckhardt, imprimindo novos desdobramentos à concepção do Renascimento como época histórico-cultural.

\section{Referências}

BOLL, F. Sphaera. Neue griechische Texte und Untersuchungen zur Geschichte der Sternbilder. Leipzig: Teubner, 1903.

BURCKHARDT, J. Die Cultur der Renaissance in Italien. Basel, 1860.

A Cultura do Renascimento na Itália: um ensaio. São Paulo: Companhia das Letras, 1991.

Die Malerei nach Inhalt und Aufgaben. In: Jacob Burckhardt Werke. Band 16. München; Basel: C.H. Beck; Schwabe, 2006.

Beiträge zur Kunstgeschichte von Italien: das Altarbild; das Porträt in der Malerei; die Sammler. In: Jacob Burckhardt Werke. Band 6.
München; Basel: C. H. Beck; Schwabe \& Co., 2000.

Gesammelte Werke. Band II. Die Baukunst der Renaissance in Italien. Basel/Stuttgart: Schwabe \& Co. Verlag, 1978.

Gesammelte Werke. Band III. Die Kultur der Renaissance in Italien. Basel/Stuttgart: Schwabe \& Co., 1978.

. L'arte italiana del Rinascimento. Volume II. Pittura: I generi. (A cura di Maurizio Ghelardi). Venezia: Marsilio Editori, 1992.

$\frac{1}{1993 .}$. Lettere (1838-1893). Palermo: Sellerio,

Sobre a História da Arte como objeto de

uma cátedra acadêmica. Tradução e 
apresentação de Cássio Fernandes). In: MARTINS, Estevão Rezende (org.). A História Pensada. Teoria e método na historiografia europeia do século XIX. São Paulo: Editora Contexto, 2010.

FERNANDES, C. S. Aby Warburg e o problema da mudança do estilo na arte do Renascimento. In: Figura. Studi sull immagine nella tradizione classica, v. 5, p. 71-101, 2017.

Aby Warburg e Franz Boll: a astrologia no Renascimento. In: RAGAZZI, Alexandre; MENESES, Patrícia D.; QUÍRICO, Tamara (org.). Ensaios Interdisciplinares sobre 0 Renascimento Italiano. São Paulo: Editora da UNIFESP, 2017, p. 231-256.

. De Arsenal a Laboratório (1927), de Aby Warburg: Apresentação e tradução. In: Figura. Studi sull immagine nella tradizione classica, v. 4, p. 163-196, 2016a.

Jacob Burckhardt e os colecionadores no Renascimento italiano. In: HOFFMANN, Ana Maria Pimenta; BRANDÃO, Angela; SCHIAPPACASSE, Fernando Guzmán; SOLAR, Macarena Carroza (org.). História da Arte: Coleções, Arquivos e Narrativas. Bragança Paulista: Editora Urutau, 2016b, p. 47-60.

. Jacob Burckhardt e o Renascimento na Itália. In: LOPES, Marcos A. \& BENTIVOGLIO, Julio. (Org.). A constituição da história como ciência: de Ranke a Braudel. Petrópolis: Vozes, 2013, p. 59-90.

Jacob Burckhardt e Aby Warburg: da arte à civilização italiana do Renascimento. Revista Locus, v. 12. Juiz de Fora: Editora da UFJF, p. 127-143, 2007.

GOMBRICH, E. H. Aby Warburg: una biografía intelectual. Madrid: Alianza, 1992.

MÜNTZ, E. Les collections des Médicis au quinzième siècle. Paris, 1888.

VILLANI, F. Vite degli uomini illustre fiorentini. Trieste: Sezione Letterario-Artistica del Lloyd Austriaco, 1848.

WARBURG, A. A Presença do Antigo. Escritos Inéditos. Vol. 1. (Organização, introdução e tradução: Cássio Fernandes) Campinas: Editora da UNICAMP, 2018.

Die Erneuerung der Heidnischen Antike. Band I. Leipzig; Berlin: B. G. Teubner, 1932.

Opere II. La Rinascita del Paganesimo

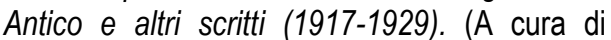
Maurizio Ghelardi) Torino: Nino Aragno Editore, 2008.

WÖLFFLIN, H. Jacob Burckhardt und die Kunst. In: WÖLFFLIN, H. Gedanken zur Kunstgeschichte. Basel: Schwabe \& Co. Verlag, 1946.

\section{Notas}

\footnotetext{
* Professor Associado do Departamento de História da Arte da Universidade Federal de São Paulo. Este texto é parte dos resultados do Projeto de Pesquisa Regular (2017/18551-4) intitulado "Aby Warburg e a astrologia", financiado pela FAPESP (Fundação de Amparo à Pesquisa do Estado de São Paulo). E-mail: <cassiofer@hotmail.com>. ORCID: < https://orcid.org/0000-0002-4159-4824>.

1 Tratamos especificamente desta conferência na ocasião de sua primeira edição em língua portuguesa (Fernandes, 2016: 163-196).

2 Trecho citado em Burckhardt, J. Die Cultur der Renaissance in Italien, Basel, 1860, p. 401. Tradução brasileira: Burckhardt (1991: 290).

${ }^{3}$ A conferência foi tratada por nós em: Fernandes (2017: 231-256).

4 Tratamos esse tema anos atrás: Fernandes (2007: 127-143).

5 Jacob Burckhardt utiliza o termo Confraternitäten no original em alemão, visto que na Itália da época o termo utilizado para caracterizar estas associações de leigos é confraternità. No Brasil, essas associações de leigos receberam o nome de irmandades.

${ }^{6}$ Desenvolvemos esta discussão em: Fernandes (2017: 71-101).

7 papel de Poliziano como autor do projeto iconográfico dos painéis de Botticelli é posto em dúvida pela historiografia da arte do final do século XX.

${ }^{8}$ Warburg menciona em nota, na edição da conferência de 1927 a seguinte edição: Müntz, E. Les collections d'antiquites formées par les Médicis au XVI siècle, Paris, 1895. No entanto, o livro de Eugène Müntz, havia sido publicado também numa versão anterior, em 1888, a qual fora utilizada por Burckhardt em seu estudo sobre o colecionismo: Müntz, E. Les collections des Médicis au quinzième siècle. Paris, 1888
}

Artigo recebido em maio de 2020. Aprovado em agosto de 2020. 